\title{
SINDROMUL BARDET-BIEDL - PREZENTARE DE CAZ
}

\author{
Sorin Ioan Iurian ${ }^{1,2}$, Heleen Arts ${ }^{3}$, Han Brunner ${ }^{3}$, Dana Fîntînă² \\ ${ }^{1}$ Universitatea ,Lucian Blaga“, Sibiu \\ ${ }^{2}$ Spital Clinic de Pediatrie, Sibiu \\ ${ }^{3}$ Departamentul de Genetică Medicală, Universitatea Radboud, Nijmegen, Olanda
}

\begin{abstract}
REZUMAT
Sindromul Bardet-Biedl (transmitere autozomal-recesivă) este caracterizat prin obezitate, degenerescență retiniană, polidactilie şi retard mental. Autorii prezintă demersul diagnostic la un sugar cu paratrofie, polidactilie şi hipogenitalism.
\end{abstract}

Cuvinte cheie: sindrom Bardet-Biedl, paratrofie, polidactilie

\section{INTRODUCERE}

Sindromul Bardet-Biedl este o afecțiune ce include multiple anomalii: tulburări de vedere, polidactilie, retard psiho-motor şi obezitate debutată în perioada de sugar.

\section{Istoric}

La sfârşitul secolului al XIX-lea, John Laurence şi Robert Moon au descris 4 pacienți cu retinită pigmentară, retard mental, parapareză spastică, hipostatură şi hipogonadism. Ulterior (1920), George Bardet, analizând cazuri cu obezitate hipotalamică, a descris un grup de pacienți ce prezenta obezitate, retinită pigmentară şi hexadactilie. Apoi, în 1922, Artur Biedl a publicat un studiu analizând pacienţi cu polidactilie, retard mental şi retinită pigmentară. În 1925 s-a concluzionat că afecțiunile menționate de cei patru medici reprezintă una şi aceeaşi boală, atribuindu-i-se numele de sindromul LaurenceMoon-Bardet-Biedl (SLMBB). Recent însă acest sindrom a fost împărțit în sindromul LaurenceMoon, caracterizat prin parapareză spastic şi retard mental, şi sindromul Bardet-Biedl (SBB) ce include obezitate, polidactilie şi dificultăți în procesul de învățare (entitatea mai frecventă).

\section{Etiologie}

SBB face parte din categoria ciliopatiilor alături de afecțiuni ca dischinezia ciliară primară/sindromul Kartagener, hidrocefalia, boala polichistică renală, sindromul Meckel-Gruber sau sindromul Joubert, (1). Background-ul genetic este heterogen, fiind descrise până în prezent 15 gene răspunzătoare de SBB. La unii pacienţi s-a demonstrat transmiterea ,tri-alelică“" prin asocierea a două alele de pe acelaşi locus cu o alelă aparținând unui locus secundar (2). Cele mai frecvente gene implicate sunt: $B B S 1$, $B B S 2, B B S 10$ şi $B B S 12$, screening-ul acestor gene identificând aproximativ $62 \%$ dintre pacienții cu SBB, (3). Anomalia BBS12 (genă specifică vertebratelor) răspunde de $6 \%$ din cazurile de SBB. Genele $B B S 12, B B S 6$ şi $B B S 10$ fac parte din categoria superfamiliei chaperoninelor tip II şi sunt implicate în mod caracteristic în funcția ciliară (4).

În funcție de gena interesată, au fost descrise câteva variante fenotipice ale sindromului BardetBiedl (2):

- anomaliile genelor BBS2 şi BBS4 se asociază cu retard statural;

- afectarea genei BBS3 este responsabilă de polidactilie limitată strict la nivelul membrelor inferioare, obezitate şi IQ redus; 
- pacienții cu anomalia genei BBS5 prezintă degenerescență maculară gravă şi brahidactilie/sindactilie (însă fără polidactilie);

- anomalia genei BBS6 poate determina sindromul McKusick-Kaufman, afecțiune cu fenotip asemănător sindromului Bardet-Biedl (5).

Fiziopatologic, boala este consecința interacțiunii dintre factorii genetici şi disfuncţia ciliară. Dacă disfuncția cililor tubilor renali este majoră, atunci afectarea renală este importantă, reprezentând principala cauză de mortalitate (6).

\section{Epidemiologie}

Prevalenţa bolii în America de Nord şi Europa este 1:140.000 - 1: 160.000 nou-născuți. Se remarcă prevalența crescută a bolii $(1: 13.500)$ la populația arabă beduină din Kuweit. Raportul pe sexe este de 1,3:1 în favoarea sexului masculin.

Pacienții cu SBB prezintă următoarele anomalii, (7):

- obezitate ( $83 \%$ dintre pacienti);

- retard mental(IQ sub 79 la 77\% dintre pacienți);

- anomalii oculare: distrofie retiniană $(100 \%)$, miopie $(75 \%)$, astigmatism (63\%), nistagmus $(52 \%)$, glaucom $(22 \%)$, cataractă capsulară posterioară (44\%) şi retinită pigmentară $(8 \%)$;

- anomalii cardiace: hipertrofie sept interventricular şi ventricul stâng, cardiomiopatie dilatativă;

- anomalii membre: polidactilie postaxială (58\%), sindactilie, brahidactilie (50\%);

- anomalii aparat urinar: calice malformate $(95 \%)$, chiste renale $(62 \%)$, cicatrici renale (24\%), ectopie uretră;

- anomalii organe genitale: hipogenitalism (micropenis, microorhidie), duplicație uterină, hipoplazie uterină, vagin septat, atrezie vaginală;

- alte anomalii: fibroză hepatică, diabet zaharat, diabet insipid, clinodactilie deget $\mathrm{V}$, surditate, disgenezie hipocampică.

În evoluție, pacienții pot prezenta simptome neuropsihice (boala obsesiv-compulsivă, dificultăți de atenție), schizofrenie, ataxie, acidoză tubular renală, insuficiență renală, hipertensiune arterială, astm bronşic ( 25 dintre cazuri). Acuitatea vizuală se deteriorează odată cu vârsta.

\section{Investigații}

Diagnosticul probabil se stabileşte pe criterii clinice, iar confirmarea necesită testare genetică pentru a diferenția SBB de alte boli genetice rare.
Evaluarea funcțiilor renală şi cardiacă (serologic şi imagistic) este recomandabilă pentru aprecierea prognosticului.

\section{Tratament}

$\mathrm{Nu}$ există terapie specifică.

Prognosticul este rezervat odată cu alterarea functiei renale.

\section{Profilaxie}

Sfatul genetic şi testarea genetică a genitorilor (preconcepție) sunt utile.

\section{PREZENTARE DE CAZ}

Sugarul C.V.N., în vârstă de 5 luni, se internează în secția de pediatrie pentru evaluare clinico-paraclinică şi tratament în contextul în care prezintă respirație dificilă, wheezing, tuse şi obstrucție nazală.

Antecedente heredo-colaterale: părinţi sănătoşi, fără relații de consangvinitate; mama VI Gesta V Para (un avort spontan). Rangul copilăriei: al 5-lea copil; doi frați sănătoşi şi două surori sănătoase; o soră (15 ani) a prezentat în copilărie anomalii ale dentiţiei primare (schimbarea incisivilor centrali arcadă superioară de 4 ori în primii 8 ani de viață). Antecedente obstetricale: naştere spontană (prezentație craniană) la vârsta gestațională de 9 luni, fără suferință la naştere; greutate $3.800 \mathrm{~g}$; APGAR $=10 / 1$ minut.

Din istoricul pacientului reținem: 3 internări justificate de bronşiolită acută.

Examenul obiectiv la internare: stare generală medie, țesut adipos foarte bine reprezentat global, $\mathrm{G}=10,8 \mathrm{~kg}$ (> percentila 95 ), perimetrul cranian = $41 \mathrm{~cm}$, dismorfism facial (fante palpebrale cu dispoziție mongoloidă, păr jos inserat anterior), paloare tegumentară, mamelon rudimentar hemitorace bilateral (politelie), xerodermie, dermatită seboreică scalp, plică simiană; gât scurt, semne rahitism, anomalii degete (brahidactilie, polidactilie post-axială picior bilateral, sindactilie parțială degete 5 şi 6 picior stâng); hipotonie axială; raport braț/antebraț subunitar $(<1)$; raport vertex-pube/ pube-plantă $>1$ (supraunitar); obstrucție nazală, rinoree seroasă, 46 respirații/minut, tuse spastică, wheezing, dispnee expiratorie, expir prelungit, raluri sibilante diseminate; zgomote cardiace ritmice, suflu sistolic grad I/6, AV = 120/minut; abdomen depresibil, faringe congestionat; rinichi nepalpabili, urini ce nu pătează scutecul, hipogenitalism (micropenis), testiculi descinşi în scrot şi de mici dimensiuni; fără semne de iritaţie meningeală; 
retard psiho-motor (achiziții motorii corespunzătoare vârstei de 2 luni).

\section{Investigații}

Evaluări serologice: leucocite 12.190/ $\mathrm{mm}^{3}$ (limfocite $67 \%$, neutrofile $17 \%$, monocite $13 \%$ ), hemoglobină $=10,6 \mathrm{~g} \%$; trombocite $=395.000 / \mathrm{mm}^{3}$; proteina $\mathrm{C}$ reactivă $=1 \mathrm{mg} / \mathrm{l}($ normal $<10)$, bilanț hepato-renal în limite normale; valori normale pentru fier, glucoză, colesterol şi trigliceride; alfa 1 -antitripsină - valori normale.

Examen de urină în limite normale.

Test iontoforeză: dozare $\mathrm{Cl}^{-}$în sudoare $=32$ $\mathrm{mMol} / 1$ (normal $<40 \mathrm{mMol} / \mathrm{l})$.

Explorări imagistice: ultrasonografia abdominală fără modificări patologice; ecografia cardiacă a relevat hipertrofie moderată a septului interventricular şi ventriculului stâng.

Examen fund de ochi: fără modificări patologice retiniene.

Diagnosticul diferențial a inclus următoarele afecțiuni:

- sindromul Bardet-Biedl poate fi considerat ca posibil întrucât sugarul prezintă suprapondere, polidactilie şi hipogenitalism;

- sindromul Laurence-Moon (SLM) ce evoluează cu parapareză spastică; comparativ cu SBB, polidactilia lipseşte la pacienții cu SLM, în consecință se exclude la caz;

- sindromul Cohen se caracterizează prin retard mental, microcefalie, hipotonie, mobilitate articulară crescută, miopie, distrofie retiniană şi obezitate tronculară cu debut la adolescență şi dismorfism facial (nas bulbos, incisivi centrali superiori proeminenți). Absența microcefaliei şi dismorfismului facial ca şi debutul precoce al obezităţii exclude această boală;

- sindromul Alstrom este o boală genetică cu transmitere autozomal-recesivă, ce se manifestă din perioada de sugar, şi care evoluează cu hipostatură, distrofie retiniană cu pierderea progresivă a vederii, obezitate, cardiomiopatie dilatativă, diabet tip 2 şi surditate (8); această boală nu poate fi exclusă;

- sindromul McKusick-Kaufman (SMKK) se caracterizează prin triada polidactilie, malformație cardiacă congenitală şi anomalii organe genitale $(9,10)$; manifestările clinice sunt comune cu cele din SBB, exceptând tulburările de vedere, obezitatea şi insuficiența renală, specifice doar SBB; obezitatea instalată precoce la caz face SMKK puțin probabil;

- sindromul Carpenter se caracterizează prin craniostenoză, anomalii degete (polidactilie, brahidactilie, sindactilie cutanată), dizabilitate intelec- tuală, obezitate cu debut precoce şi dismorfism facial (fante palpebrale cu dispoziție anti-mongoloidă, urechi jos inserate) (11); în lipsa craniostenozei se exclude această afectiune;

- sindromul Simpson-Golabi-Behmel este compatibil cu macrosomie, facies grosolan (nas lat, hipertelorism, macrostomie), mameloane rudimentare (politelie), polidactilie post-axială, hepatosplenomegalie, malformație cardiacă şi anomalii renale (12); faciesul nesugestiv şi absența hepato-splenomegaliei face această boală puțin probabilă;

- sindromul Prader-Willi este o boală caracterizată prin hipotonie, obezitate cu debut în copilărie, diabet tip 2, retard mental, mâini şi picioare scurte, organe genitale subdezvoltate (13); din cauza debutului obezității în perioada de sugar, boala se consideră puțin probabilă.

\section{Diagnostic pozitiv}

Caracteristicile fenotipice (paratrofia, polidactilia post-axială, sindactilia parțială, anomalia organelor genitale) corelate cu malformația cardiacă (hipertrofia septală şi ventriculară stângă) au orientat diagnosticul spre SBB, justificându-se testarea genetică (Nijmegen, Olanda) constând în screening-ul tuturor genelor asociate cu SBB. S-a testat sugarul şi ambii genitori, utilizând secvențierea de nouă generație (,next generation DNA sequencing“). Testarea genetică a relevat mutaţia homozigotă „nonsense“ a genei BBS12 (c.1063C > T, p.Arg. 355), mutaţie ce a fost raportată prima dată de Stoetzel şi colaboratorii în 2007 (4). Ambii părinți au fost identificaţi ca purtători heterozigoți pentru aceeaşi mutație.

S-a stabilit diagnosticul de SBB la un sugar cu bronşiolită acută şi wheezing recurent.

\section{Tratament}

Terapia bronşiolitei a inclus: beta $_{2}$-simpaticomimetice inhalatorii, corticoterapie iv şi vitamina $D$ po, evoluția fiind lent favorabilă. Pentru SBB nu există terapie specifică.

În evoluție, sugarul necesită:

- dietă hipocalorică şi evaluare curbă ponderală în evoluție;

- monitorizare clinică;

- monitorizare terapeutică: inițierea terapiei cu blocanți receptori leucotriene în caz de wheezing persistent, după vârsta de 6 luni;

- evaluare biologică periodic (semestrial): glicemie, bilanț funcțional renal, profil lipidic, bilanț endocrinologic cu testarea funcției tiroidiene şi a testosteronului seric; 
- evaluare imagistică anuală (ecografie abdominală şi cardiacă);

- evaluare anuală oftalmologică;

- se are în vedere corecția chirurgicală a polidactiliei.

\section{CONCLUZII}

1. Autorii prezintă cazul unui sugar cu paratrofie, polidactilie postaxială şi anomalii genitale, caz confirmat genetic ca şi SBB.
2. Considerăm utilă testarea genetică şi a fraților şi surorilor probantului, având în vedere fenotipul variabil (de la forme moderate la forme severe de boală).

3. Se impune sfatul genetic pentru limitarea riscului de transmitere a bolii în familie.

4. În fața unui pacient cu obezitate, polidactilie postaxială şi disabilitate mentală, trebuie avută în vedere posibilitatea sindromului Bardet-Biedl. 